\title{
The Effect of Technological Innovation on Employee Performance in Pandemic Era: Case from Banking Industry in Indonesia
}

\author{
Sekar Wulan Prasetyaningtyas*, Aishah, Brenda Regina Hansen, Deviana Kuspriandani \\ Master of Management Program, Binus University, Indonesia \\ *corresponding author e-mail: sekar@ binus.edu
}

\begin{tabular}{l}
\hline Article Info \\
\hline Keywords: \\
Technology innovation; \\
Job satisfaction; \\
Work-life balance; \\
Burnout; \\
Performance \\
\hline
\end{tabular}

JEL Classification:

L29, 0310, M12

DOI:

10.33830/jom.v17i2.1921.2021

\section{Article History}

Received: August 9, 2021

Accepted: October 28, 2021

Published: November 15, 2021

\begin{abstract}
This study assessed the impact of technological innovation on employee performance, especially during the COVID-19 pandemic situation. Data were gathered from private and government banks that applied technological innovations to the COVID-19 Pandemic. The author also elucidated more about the influence of technological innovation on employee performance, influenced by job satisfaction, work-life balance, and burnout. This study described technological innovation within the Jabodetabek Area's banking industry by using variables that affect employee performance. The questionnaires were distributed through social media to 123 respondents under 40 years of work. The data were then analyzed using PLS-SEM through SmartPLS 3 software. Findings. The results of this study indicated the positive effect of technological innovation on the performance of bank employees. Utilizing technological innovation will increase employees' satisfaction at work, balance employees' lives, reduce burnout, and improve employee performance eventually. This paper focused on the variables used in the banking industry, especially in COVID-19 Pandemic. Mediating variables used also have never been explored in the previous research.
\end{abstract}

\section{Introduction}

The COVID-19 pandemic has triggered many changes around the world since its emergence in December 2019 in China and early March 2020 in Indonesia. Therefore, WHO approached each country to find ways to regulate the spread of COVID-19. The existence of state regulations to maintain social distancing and stay at home to break the chain of the spread of COVID-19 has encouraged organizations to understand work from home (WFH). The number of WFH workers is 1.25 million from 3,788 organizations (Yuliani, 2020). The coronavirus pandemic has also changed people's lives. Due to the COVID-19 Pandemic, three things have changed regarding the workforce: More Technology, Automation and Less Mobility (Catriana, 2020).

The COVID-19 pandemic has also had an impact on Islamic banking. Based on published reports available on the Financial Services Authority (OJK) website, it shows that the total assets of two of the three sharia banks owned by state-owned enterprises (BUMN) in Indonesia decreased in the second quarter of 2020 compared to the previous quarter. Bank Syariah Mandiri and Bank 
BNI Syariah respectively recorded total assets of Rp114.40 trillion and Rp50.76 trillion in the second quarter of 2020, in the previous quarter, both recorded total assets of Rp114.74 trillion and Rp51.12 trillion (Annur, 2020). The results of the performance shown by the company do not escape the important role of the company's human resources. Companies need superior human resources who must be built carefully and firmly, especially in dealing with bad situations such as the COVID-19 pandemic.

Innovations made by the company for ease of service to consumers and employees in carrying out work activities. Thus, the COVID-19 pandemic condition requires employees to be proficient in utilizing technological advances. The existence of technological innovations carried out by the company is expected to be able to support employees in work activities and achieve employee performance. The role of technology during a pandemic includes means of communication between employees, optimizing and streamlining jobs that require technology, especially jobs that are redesigned to be done online or work from home (WFH) (Yudianto \& Nurpratama, 2021).

In the COVID-19 pandemic situation, employees are dependent on technology in completing office work flexibly from home and are also responsible for helping children in carrying out online learning at home. With the existence of work from home, employees who have families face two roles, namely roles at work and family at the same time, this causes work-life balance and burnout to not be achieved. Burnout can occur when the boundaries between work and personal hours are blurred. In addition, employees are required to work more, stay connected, and maintain communication. This dependence on technology becomes a further burden on resources that have experienced stress which leads to technostress (Stefanie et al., 2020). Burnout and technostress due to the application of working flexibly from home can reduce employees' ability to perform their job duties (Greenberg \& Baron, 2000; Stefanie et al., 2020). In addition, work from home causes a significant loss of face-to-face time and more social isolation reduces job satisfaction (Stefanie et al., 2020).

Based on previous research, there is a relationship between technological innovation on job satisfaction, work-life balance, and burnout on employee performance. Research results from Ratna (2016) found that new technology has a strong impact on job satisfaction, work-life balance, and employee performance. Technological innovation due to new technology that can help complete their responsibilities within a certain period has an impact on employee satisfaction. Besides being able to increase job satisfaction, technological innovation can also reduce the occurrence of burnout. Salanova and Schaufeli (2000) suggest that technological exposure to burnout results in lower burnout rates. Also, new technologies can balance life. Work-life balance has a significant effect on employee performance (Akpa et al., 2019).

Based on the phenomena that occurred during the pandemic and previous research, the authors are interested in examining more deeply the impact of technological innovation on employee performance mediated by job satisfaction, work-life balance, and burnout, especially in the banking industry. Performance measurement in this study refers to indicators of quality and effectiveness (related to KPIs that were not included in the study); The usual banking KPI targets are not related to the work indicators studied with the COVID-19 Pandemic situation. The purpose of the study was to determine the effect of technological innovation on Job Satisfaction, WorkLife Balance, and Burnout on Employee Performance in the Pandemic Era. This study provides several new perspectives from research on how technological innovation is associated with job satisfaction, work-life balance, and burnout on employee performance for the banking industry in the COVID-19 pandemic era. 
Data innovation (IT) uses any PCs, accumulating, arranging, and other actual devices, establishment, and cycles to shape, measure, store, secure, and exchange a wide range of electronic data. Generally, IT is used concerning attempts exercises as opposed to individual or redirection headways. Innovation is a social cycle wherein technical information and creations are specifically misused to benefit (corporate or government) institutional plans, driven by commercial center qualities or political arrangements (Goldman, 2020).

Competitors in the banking industry learn about new technologies and new market opportunities simultaneously (Kotoroi, 2015). They were further stated by Ameme and Wireko (2016) that this technology would have the most significant influence on the banking business in the future. Based on the above understanding, it can be concluded that information technology innovation is something new or is an essential improvement in the form of products, processes, and services to create, process, store, secure. Also, exchange all electronic data documents using computers, storage, networks and devices, other physical activities carried out selectively on behalf of an institutional (corporate or government) plan driven by market values or political policies.

According to Ndulue and Ekechukwu (2016) and Cranny (2014), job satisfaction is representatives' emotional state regarding work, considering what they expect and what they get from it. Further, representatives have defined objectives and qualities as a top priority, and if their work helps them accomplish those objectives, they are fulfilled. In the meantime, as per Ezeanyim et al. (2019), work fulfillment accomplishes representatives' impression of how well their work gives things that are viewed as necessary.

According to Sutrisno (2011), job satisfaction is impacted by a few variables: pay, employer stability, openings for progression, the executives and friends, directors and bosses, poor management can bring about nonattendances and turnover, a genetic factor of work, trouble or simple and pride in the undertaking can increment or decline work, working conditions which incorporate bottles, ventilation, stopping and broadcasting, social parts of work, correspondence and friends' offices.

In the banking industry, employee satisfaction, according to Awan and Asghar (2014), is the reason for giving a good performance, the level of involvement is very high in various ways, and lower resignation rates. A few investigations recommend that work fulfillment plays a fundamental part in driving many wanted occupation outcomes. As per the social trade hypothesis, representatives happy with their functioning conditions are bound to show association as an equal instrument for associations that have advantages (Aselage \& Eisenberger, 2003). Some proof shows that the work fulfillment of administration representatives is straightforwardly or in a roundabout way identified with inspirational perspectives, goals, practices, and work results at both the individual and unit levels.

Work-Life Balance concerns how representatives can utilize flexible functioning hours to adjust their work or work with different responsibilities like family, side interests, craftsmanship, studios, and not just spotlight their work. Parkes and Langford (2008) characterize balance between fun and serious activities as a person who can resolve to work and family and is liable for both non-work exercises.

As per Handayani et al. (2015), Work-Life Balance is when an individual can share jobs and feel fulfillment in these jobs, shown by the low degree of work-family struggle and the high familylevel help work or family improvement work. Greenhaus et al. (2003) expressed that balance between serious and fun activities is how people are bound and happy with work life and everyday life and adjust to work and family. 
According to Lockwood (2003), work-life balance is a condition that demands a balance between one's work and life to be the same. According to employees, the work-life balance is a choice in managing work obligations and personal (family) obligations. To summarize, work-life balance is harmony between jobs in and outside of work where there is a negligible struggle between the association's situations and the capacities in life representatives. Offset is additionally connected with fit representatives keeping up with and feeling the concordance of life in work and jobs in the area. A worker will progress close to home life and work-life fulfillment when the commitment between his time and position works out positively.

Burnout is a complex condition including enthusiastic weariness, depersonalization, and individual achievement. Intense weariness means sensations of being sincerely depleted and drained; depersonalization (alluded to as criticism) indicates sensations of separation from work; individual activity alludes to one's feeling of ability and accomplishment at work (Schaufeli \& Greenglass, 2001). Burnout (depersonalization and emotional depletion) is equal (Demerouti et al., 2005). Mental exhaustion is caused by long-term involvement in an emotionally demanding situation. This condition is described as follows: (1) psychological burnout is characterized by low energy, chronic burnout, and weakness, (2) emotional exhaustion, the second component of burnout, especially involving feelings of helplessness and hopelessness, (3) mental burnout, which is characterized by negative attitudes towards self, work, and life.

According to Ciner (2019), performance is how an employee fulfills his job duties and carries out the required tasks. Meanwhile, Ezeanyim et al. (2019) stated that performance is a function of individuals' and businesses' abilities and skills in certain situations. In the short term, employees' skills and abilities are relatively stable. Performance in terms of effort extends to the job of an employee. According to Taghipour and Dejban (2013), performance is defined as the level of success of a person in performing tasks and achieving predetermined goals. Performance can be said to be successful and has been good if the desired objectives have been achieved properly. According to Ndulue and Ekechukwu (2016), the definition of performance is a function of the abilities and skills of individuals and businesses in certain situations. In the short term, the skills and abilities of employees tend to be more stable, whereas they are broadly more related to the work of employees.

Based on many experts' opinions on performance, it can be interpreted as a result of work done by someone in a company or organization to achieve its goals and minimize losses. In other words, we can interpret performance as a willingness of an individual or group to carry out their duties and complete them according to their responsibilities and as expected.

Organizations that have understood the main benefits of innovation have human assets. The executives rehearse that help utilizes innovation to make what is known as an elite work framework (Ratna, 2016). Workers' impression of advancement straightforwardly sways their degree of fulfillment (Sockel et al., 2004). In light of research by Attar and Sweis (2010), the outcomes show that more significant interest in innovation is desirable over increment worker to work fulfillment from both an inborn and extraneous and general perspective. The Bank amplifies its IT innovation advancement abilities as a novel and essential asset to give a top-notch, imaginative yield that builds worker fulfillment levels (Obeng \& Boachie, 2018).

$\mathbf{H}_{1}$ : IT technological innovation has a positive impact on the employee satisfaction

New technologies can enable us to work faster and more efficiently. It can facilitate flexible and remote work, i.e., work from home, prepare presentations and brief reports using cell phones other than computers and laptops, but that can also mean that we can never really go on and off (Ratna, 2016). These correlate for technological innovation with employees, whereby 
technological innovation impacts work-life balance (Fazili \& Khan, 2017). Advanced technology helps employees balance their lives (Al-Saidi, 2015). Based on the results of Fazili and Khan (2017), technological innovation has an impact on work-life balance.

$\mathbf{H}_{2}$ : IT technological innovation has a positive impact on work-life balance

Besides being able to balance work-life, new technology can also reduce burnout. However, it cannot be denied that technology exposure affects the mental health and wellbeing of users in both positive and negative terms (Salanova $\&$ Schaufeli, 2000). Technologies that depend on how technology is introduced can lead to higher saturation levels or become tools to help fight saturation (Sockel et al., 2004). Perceptions of new technology are organizational factors that firmly explain (negatively) burnout (Knani, 2013). If new technology is introduced and managed well, it can lower burnout levels (Sockel et al., 2004).

$\mathbf{H}_{3}$ : IT technological innovation harms burnout

When work becomes more proficient because of innovation that assists with being more compelling, it will limit burnout, make harmony among work and individual life, and make work fulfillment for representatives. Representatives will work willfully. Work is the inner strength of somebody who readily works when representatives are happy with their work and their necessities are met. They foster a connection to work, or we say they are attempting to work better, which will prompt better execution (Ezeanyim et al., 2019). Moreover, Tabassum et al. (2016) characterize work fulfillment as sure feelings from a worker in an association about the work he does and the encounters he lands from his position. Fulfilled workers show positive responsibility and better the association, driving the association to progress (Tabassum et al., 2016) additionally upheld this sort of hypothesis, uncovering the beneficial outcomes of individual occupation fulfillment on a few parts of people's work execution.

H4: Job Satisfaction features a positive effect on employee performance

Several empirical studies have shown that work-life balance experiences are positively related to employee performance (Kim, 2014; Harrington \& Ladge, 2009; Parkes \& Langford, 2008). Work-life balance contributes to improving performance in employee roles (Kim, 2014). Based on research conducted by Akpa et al. (2019), it can be concluded that work-life balance has a significant effect on performance. Work-life balance, as an essential element of HRM, does affect employee performance. Other conditions are considered the same, a better work-life balance in a company, leading to increased employee performance (Thevanes \& Mangaleswaran, 2018).

$\mathbf{H}_{5}$ : Work-Life balance can have a positive impact on performance

On the other hand, if representatives are not fulfilled and feel depleted because of their crooked life at work, the present circumstance will bring about workers done deliberately. This statement is reliable with the aftereffects of examination led by (Bakker \& Costa, 2014). They inspected the relationship between the three elements of burnout and work execution for more than three years and were among the leading creators to discover exact help for the relationship between burnout and execution. They tracked down that emotional fatigue anticipated resulting position execution. Burnout and execution are adversely identified with one another (Rehman et al., 2015). Workers who feel tired may not perform well since they should conquer issues identified with their enthusiastic and expert sentiments (Rehman et al., 2015). In like manner, Ritacco et al. (2013) expressed that burnout was contrarily associated with execution. Burnout has been distinguished in law implementation workplaces, specialists, medical caretakers, educators, and bank 
representatives (Khalid et al., 2019). Belias et al. (2013) express that burnout from work confronting relationship strains while teaming up with others. Belias et al. (2013), also Gorji and Vaziri (2018) tracked down that these individuals experience burnout much more often. The measure of passionate depletion and depersonalization they feel contrarily impacts their exhibition. It is realized that worker execution diminishes when passionate depletion and depersonalization increase, and the opposite way around. A similar outcome was additionally expressed by Belias et al. (2013) and Demerouti et al. (2005), which were directed on bank workers it was discovered that burnout expanded representative execution then, at that point, diminished.

H6: Burnout harms employee performance.

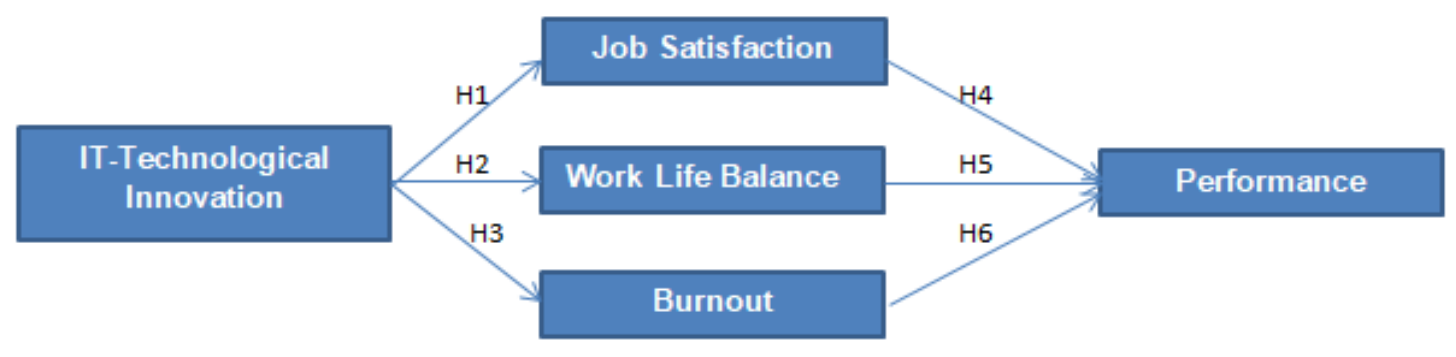

Figure 1. The research model

\section{Research Method}

This study measures IT technology innovation's effect on job satisfaction, work-life balance, and burnout on employee performance. In gathering information, the instruments used in this research include journals, online resources, and others; this is a secondary source. Meanwhile, the questionnaire has been selected as the primary source of data collection. The questionnaire used in this study for data collection is based on the extant literature. Responses on each item (related to the variable) were provided by participants using a five-point Likert scale ranging from 1 (strongly disagree) to 5 (strongly agree) (Brown \& Peterson, 1994). "1" means "strongly disagree," "2" means "disagree," "3" means "neutral," "4" means "agree," and "5" means "totally agree."

The questionnaire used in this study consisted of two parts. The first part included items related to the respondents' socio-demographic information, such as work area, type of work, age, educational background, and staff grade. Meanwhile, the remaining second part is related to variables. Overall, 14 items in the questionnaire were selected after an extensive review of the relevant literature (IT technology innovation, job satisfaction, work-life balance, burnout, and employee performance), and these items measured model construction. To fits with this study's context, minor amendments were made.

IT Technological Innovation variable development was estimated by two things adjusted from Sockel et al. (2004), Osman et al. (2016) and Al-Saidi (2015). In the meantime, three things adjusted from Ratna (2016), estimated the work fulfillment variable. The balance between fun and serious activities variable was estimated by two things adjusted from Khatri and Behl (2013), Ratna (2016) and Al-Saidi (2015). The burnout variable was estimated by two things adjusted from Sockel et al. (2004), Wu et al. (2019) and Rehman et al. (2015). In contrast, the representative presentation variable was estimated utilizing five things adjusted from Ratna (2016), Osman et al. (2016) and Wu et al. (2019). 
This study used cross-sectional studies so that the impact of technological innovation on job satisfaction, work-life balance, and burnout on employee performance was possibly assessed. The population was all banking employees in Jabodetabek (Jakarta, Bogor, Depok, Tangerang and Bekasi) area, max-age 40 years old, education min associate degree and position levels ranging from the clerk, junior manager, manager, and senior manager. As for the sampling technique, we are using non-probability sampling with the purposive sampling method. For determining the minimum sample size based on Daniel (2015), Hair et al. (2011) stated that the number of samples as respondents adjusted to the number of question indicators used in the questionnaire, assuming $n \times 5$ observed variables (indicators) up to $n \times 10$ observed variables (indicators). Based on this, with the number of indicators before the pretest was 45 , the authors used a minimum sample of 225 respondents. Statistically, it is stated that the larger the sample size is expected to give better results (Hair et al., 2011).

Primary data were collected by giving questionnaires to bank employees in the Jabodetabek. The questionnaire was taken online considering the COVID-19 pandemic conditions. Three hundred forty-seven respondents filled out the questionnaire. After the screening, 225 respondents were used as the samples for this study.

This study used PLS-SEM analysis so that a complex and simultaneous variable test was carried out. This study uses several independent and mediating variables to measure the dependent variable. Can handle very complex relationships, the academic needs are more flexible, optimal in prediction and model accuracy, the power of estimation is consistent when the number of samples increases, the latent variable scores explicitly estimated, and for optimal implications for predictive accuracy (Richie, 2019). This study used latent variables or variables which could not be measured directly. PLS-SEM with the PLS approach in forming a structural model applied to employee performance cases. The endogenous latent variables used were employee performance and exogenous latent variables that affect endogenous variables between technological innovation, job satisfaction, work-life balance, and burnout. SMART PLS 3 software determines the inner model's analysis results, outer model, and hypothesis testing for PLS-SEM analysis.

\section{Results and Discussions}

Table 1 shows the socio-demographic characteristics of the respondents. The number of respondents who filled out the questionnaire for analysis was 225 respondents. Where in this sociodemographic section, the questions given will filter out respondents according to the research target.

Table 1. Socio-demographic characteristics of the respondents

\begin{tabular}{lcc}
\hline Characteristics & Number & Percentage (\%) \\
\hline Age & 125 & 56 \\
$23-30$ & 100 & 44 \\
$31-40$ & & \\
Last education & 7 & 3 \\
Associate degree & 192 & 85 \\
Bachelor degree & 26 & 12 \\
Master degree & 0 & 0 \\
Doctoral degree & & \\
Position level & & \\
\hline
\end{tabular}




\begin{tabular}{lcc}
\hline Characteristics & Number & Percentage (\%) \\
\hline Clerk & 73 & 32 \\
Junior Manager & 116 & 52 \\
Manager & 31 & 14 \\
Senior Manager & 5 & 2 \\
\hline
\end{tabular}

The age was dominated by respondents aged $23-30$ at 56\% and aged 31-40 at $44 \%$. For the education questions, the level was dominated by bachelor degree at $85 \%$. For the position, the level was dominated by Junior Manager at $52 \%$. So based on these data, the selected respondents are following the target respondent researchers.

\subsection{Reliability and Validity Test}

Reliability and validity are concepts that are used to evaluate the quality of research. They indicate how well a technique or test measures something. Reliability is about the consistency of a measure, and validity is about the accuracy of measurement (Middleton, 2019). The validity check in this analysis was performed with appropriate parameters on SmartPLS 3 with valid criteria if the average variance extracted (AVE) of each model is equivalent to 0.5 or above. In PLS-SEM, the amounts are ordered based on their indicators' single reliability, ranging from 0 to 1; a greater rate signifies more excellent reliability. A generally accepted standard for composite reliability is 0.7 or higher. For exploratory research, Cronbach's alpha's acceptable value is above 0.6. For this study, the proper value of the reliability test $>0.7$ and Cronbach's alpha $>0.6$.

Table 2. Descriptive statistics

\begin{tabular}{lccccc}
\hline Characteristics & N & Minimum & Maximum & Mean & Std. Deviation \\
\hline Technological & 225 & 4 & 10 & 8.40 & 1.282 \\
Innovation & 225 & 4 & 15 & 11.77 & 2.072 \\
Job Satisfaction & 225 & 3 & 10 & 7.08 & 1.426 \\
Work-Life Balance & 225 & 2 & 10 & 6.20 & 1.830 \\
Burnout & 225 & 5 & 25 & 19.59 & 3.308 \\
Performance & 225 & & & & \\
Valid N (listwise) & & & & \\
\hline
\end{tabular}

Table 2 above shows that $\mathrm{N}$ or the amount of data for each valid variable is 225 . Of the 225 sample data of technological innovation, the minimum value is 4 , and the maximum value is 10 with a mean value of 8.40 and a standard deviation value of 1.282 . For 225 job satisfaction sample data, the minimum value is 4 , and the maximum value is 15 , with a mean value of 11.77 and a standard deviation value of 2.072 . For the 225 work-life balance sample data, the minimum value is 3 , and the maximum value is 10 , with a mean value of 7.08 and a standard deviation value of 1.426. For the 225 burnout sample data, the minimum value is 2 , and the maximum value is 10 , with a mean value of 6.20 and a standard deviation value of 1.830 . For 225 performance sample data, the minimum value is 5 , and the maximum value is 25 with a mean value of 19.59 and a standard deviation value of 3.308. The five variables show that the mean value is greater than the average deviation value. The data deviation that occurs is low, so the distribution of values is evenly distributed. 
Table 3 shows the results of the measurement of reliability and validity. The validity test results can be seen in the factor loading column, where all indicators are more than 0.6 , and in the AVE column, all hands are more than 0.5 , so all indicators are declared valid. As for the reliability measurement results, it can be seen in the Cronbach's Alpha and Composite Reliability columns, where the results show that all indicators are above the minimum Cronbach's Alpha (>0.6) and Composite Reliability (0.7), so that all hands are declared reliable.

Table 3. Reliability and validity test

\begin{tabular}{|c|c|c|c|c|c|c|}
\hline Variable & Indicator & $\begin{array}{c}\text { Factor Loading } \\
>0.6\end{array}$ & $\begin{array}{c}\text { Cronbach's } \\
\text { Alpha } \\
>0.6\end{array}$ & Rho_A & $\begin{array}{c}\text { Composite } \\
\text { Reliability } \\
\quad>0.7\end{array}$ & $\begin{array}{c}\text { Average Variance } \\
\text { Extracted (AVE) } \\
>0.5\end{array}$ \\
\hline Technological & TI2 & 0.888 & 0.749 & 0.750 & 0.888 & 0.799 \\
\hline \multirow[t]{2}{*}{ Innovation } & TI5 & 0.900 & & & & \\
\hline & JS1 & 0.821 & 0.754 & 0.755 & 0.859 & 0.670 \\
\hline \multirow[t]{2}{*}{ Job Satisfaction } & JS3 & 0.840 & & & & \\
\hline & JS_10 & 0.794 & & & & \\
\hline Work-life & WLB8 & 0.809 & 0.687 & 0.775 & 0.859 & 0.754 \\
\hline Balance & WLB9 & 0.924 & & & & \\
\hline \multirow{4}{*}{ Burnout } & BO1 & 0.786 & 0.681 & 0.827 & 0.854 & 0.746 \\
\hline & $\mathrm{BO} 4$ & 0.935 & & & & \\
\hline & PF1 & 0.884 & 0.918 & 0.921 & 0.939 & 0.756 \\
\hline & PF2 & 0.912 & & & & \\
\hline \multirow[t]{3}{*}{ Performance } & PF3 & 0.903 & & & & \\
\hline & PF4 & 0.858 & & & & \\
\hline & PF6 & 0.783 & & & & \\
\hline
\end{tabular}

One way to assess Discriminant validity is by measuring using the Fornell-Larcker criterion. The AVE of each latent construct should be greater than the latent construct's highest squared correlation with any other latent construct (Hair et al., 2011). Table 4 shows that the Burnout correlation variable's value is 0.864 , which is greater than the correlation between burnout from other variables. Likewise, other correlation variables show the same thing, so it can be concluded that the indicators in this study have met discriminant validity or are acceptable (sound).

Table 4. Discriminant validity

\begin{tabular}{lccccc}
\hline Characteristics & Burnout & $\begin{array}{c}\text { Job } \\
\text { Satisfaction }\end{array}$ & Performance & $\begin{array}{c}\text { Technological } \\
\text { Innovation }\end{array}$ & $\begin{array}{c}\text { Work-Life } \\
\text { Balance }\end{array}$ \\
\hline Burnout & $\mathbf{0 . 8 6 4}$ & & & & \\
Job Satisfaction & -0.147 & $\mathbf{0 . 8 1 9}$ & & & \\
Performance & -0.081 & 0.592 & $\mathbf{0 . 8 6 9}$ & & \\
Technological & -0.031 & 0.531 & 0.448 & $\mathbf{0 . 8 9 4}$ & \\
$\begin{array}{l}\text { Innovation } \\
\text { Work-Life }\end{array}$ & -0.203 & 0.600 & 0.573 & 0.501 & $\mathbf{0 . 8 6 9}$ \\
Balance & & & & & \\
\hline
\end{tabular}

\subsection{Hypothesis Testing}

The bootstrapping method tested hypothesis analysis (subsamples 500; basic bootstrapping, two-tailed) in SMART PLS 3.2.9. Hypothesis testing analysis is carried out by looking at the 
appropriate p-value, where the null hypothesis is rejected if the p-value is > 0.05 (Hair et al., 2011). The results of hypothesis testing and the correlation between variables are shown in Figure 2 .

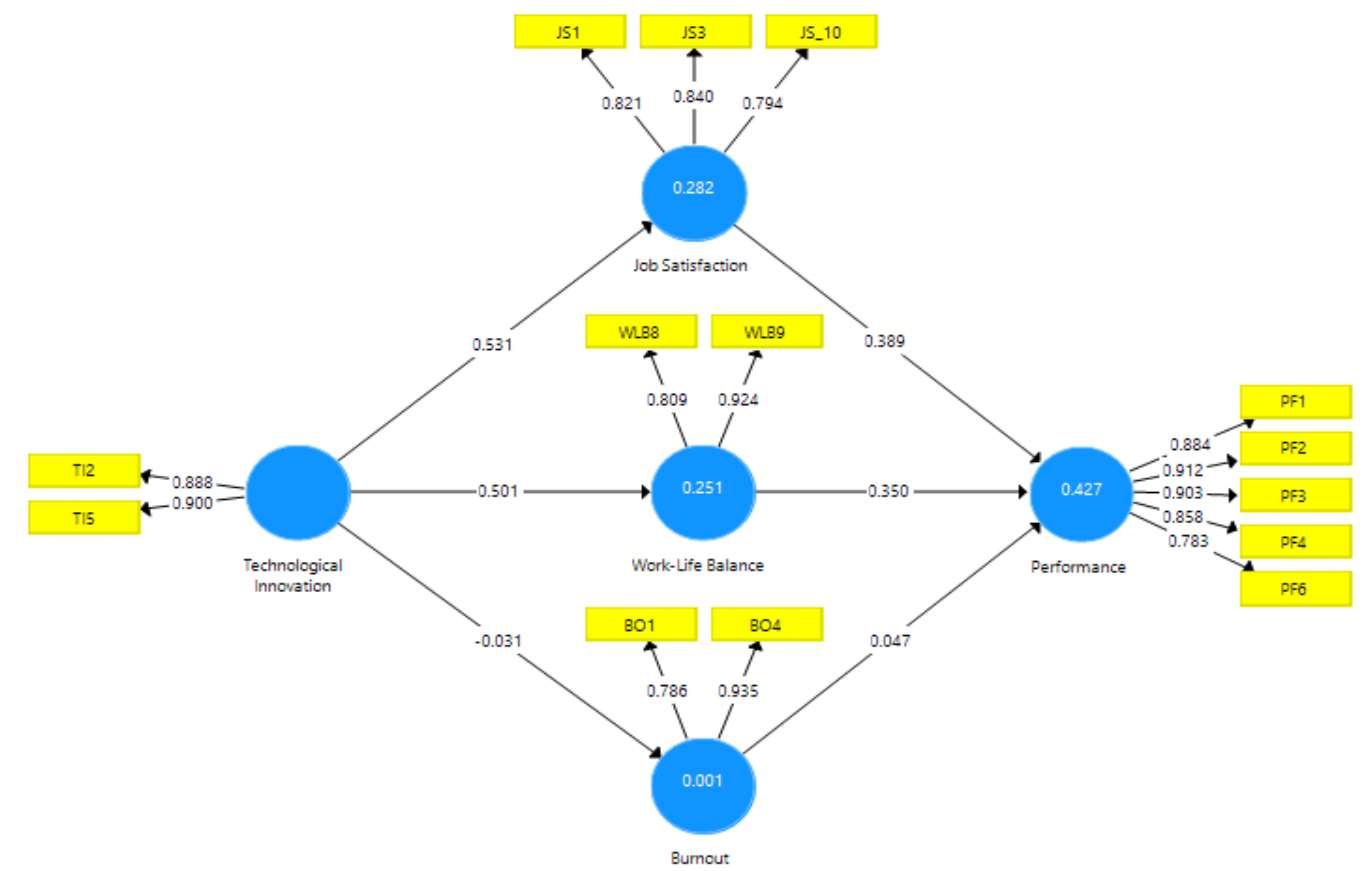

Figure 2. Result of testing model

The results of the hypotheses are presented in Table 6 . The relationship between positive and negative variables can be seen in the Original Sample column. A significant or insignificant relationship between variables can be seen in the T-statistic column and P-value.

Table 6. Hypothesis test

\begin{tabular}{lcccc}
\hline Hypothesis & $\begin{array}{c}\text { Original } \\
\text { Sample }(\mathbf{O})\end{array}$ & $\begin{array}{c}\text { T-Statistics } \\
(\mid \mathbf{O} / \text { STDEV }])\end{array}$ & P-Values & Conclusion \\
\hline $\begin{array}{l}\mathrm{H}_{1}: \text { Technological Innovation } \\
\rightarrow \text { Job Satisfaction }\end{array}$ & 0.531 & 8.760 & 0.000 & Accepted \\
$\begin{array}{l}\mathrm{H}_{2}: \text { Technological Innovation } \\
\rightarrow \text { Work Life Balance }\end{array}$ & 0.501 & 9.851 & 0.000 & Accepted \\
$\begin{array}{l}\mathrm{H}_{3}: \text { Technological Innovation } \\
\rightarrow \text { Burnout }\end{array}$ & -0.031 & 0.312 & 0.755 & Rejected \\
$\begin{array}{l}\mathrm{H}_{4}: \quad \text { Job Satisfaction } \rightarrow \\
\begin{array}{l}\text { Performance } \\
\mathrm{H}_{5}: \text { Work Life Balance } \rightarrow\end{array}\end{array}$ & 0.389 & 6.681 & 0.000 & Accepted \\
$\begin{array}{l}\text { Performance } \\
\mathrm{H}_{6}: \text { Burnout } \rightarrow \text { Performance }\end{array}$ & 0.350 & 5.603 & 0.000 & Accepted \\
\hline
\end{tabular}

Table 6 shows that Technological Innovation has a positive and significant relationship with Job Satisfaction $\left(\mathrm{H}_{1}\right)$, and Technological Innovation has a positive and significant relationship with work-life balance $\left(\mathrm{H}_{2}\right)$. This data follows the research results from Obeng and Boachie (2018), which states that the Bank maximizes its IT technology innovation capabilities as a unique and valuable resource to provide a high-quality, innovative output that increases employee satisfaction levels. Likewise, research from Fazili and Khan (2017) that technological innovation impacts 
work-life balance. Furthermore, the study results show that technological innovation has a negative and insignificant relationship with burnout $\left(\mathrm{H}_{3}\right)$. This statement follows what was conveyed by Knani (2013). New technology is a factor that harms burnout.

The respondents agreed that during the pandemic the company encouraged new ideas and prioritized technological development or innovation as a strategic step for the company to face the pandemic. However, respondents are neutral or hesitant if this affects the physical fatigue felt by employees.

Then on $\mathrm{H}_{4}$ and $\mathrm{H}_{5}$, it shows that job satisfaction has a positive and significant relationship with performance and work-life balance has a positive and significant relationship with performance. These findings follow the research of Tabassum et al. (2016) that satisfied employees show positive commitment and higher performance to the organization and a better work-life balance in a company, leading to increased employee performances. Meanwhile, H6 shows that burnout has a positive and insignificant relationship to performance. The existence of a neutral or hesitant attitude from respondents regarding the statement of physical exhausted felt during the pandemic still has an insignificant positive effect on employee performance. This is indicated by the high level of agreement from respondents on the statement that during the pandemic period employees continue to improve their skills, work more effectively, and provide better performance.

This study explores the impact of IT innovation on job satisfaction, work-life balance, and employee performance positively and significantly. Hence IT innovation usage increases employee performance. It was found that technological innovation has a positive impact on job satisfaction. The average employee agreed with the development of technology to support employees working from home during the pandemic period to provide employee satisfaction at work. Technological innovation also positively impacts work-life balance; based on the findings, the average employee feels happy at work, and the quality of work-life increases with technological innovation.

Furthermore, from the study results, there are statements related to burnout about physician burnout and feeling hopeless that has a negative relationship to technological innovation. The negative impact of this burnout is following the results of research from Knani (2013). Implementing new technology in an organization can negatively affect the employees' physical and mental health and job satisfaction/commitment. The implementation of new technology will increase perceived job demand, leading to increased levels of emotional exhaustion, depersonalization, and reduced levels of personal accomplishment.

Job satisfaction has a positive impact on employee performance; it was found that the average employee agrees that their performance can increase with a sense of pride at work. Employees agree that their work is still attractive despite working in the conditions of the COVID19 Pandemic. Work-life balance has a positive impact on employees; based on the data, and it was found that the average employee agrees that a balanced work-life can improve their performance. Meanwhile, employees working from home during the COVID-19 Pandemic can have a better time with their personal lives than before the Pandemic so that the quality of life and work improves. Lastly, burnout positively impacted employee performance, but the relationship between the two was not significant. Based on the data, it was found that the average employee felt tired at work during this Pandemic, but it did not have a substantial effect on employee performance at work.

From the discussion above, we can refer to some theories from Obeng and Boachie (2018), also Fazili and Khan (2017) that technological innovation increases employee satisfaction and impacts work-life balance. Then related with Tabassum et al. (2016), that job satisfaction has a 
positive effect on employee work performance. The last thing is work-life balance can improve performance for employees (Kim, 2014).

\section{Conclusions}

The research results proved that of the six existing hypotheses. Four were confirmed, and the remaining two were not. The analysis results show a positive relationship between innovative technology application in the work setting, job satisfaction, work-life balance, and employee performance. Meanwhile, it can be concluded from the data analysis that burnout does not significantly affect performance and that technological innovation does not considerably affect employee burnout.

From the results of this study, organizations and companies must focus on developing technological innovations and their implementation in banking business activities. Not only for customers in transactions but also for employees to help ease the work in their daily lives, especially during this Pandemic. Companies must ensure that these technological innovations are easily accessible to complete employee work during a pandemic efficiently. Companies can create technological innovations that can regulate working hours and hours for families to employees because the same day's work can be completed quickly with the help of technological innovation. So that employees can arrange and separate their time for work and their personal life.

Companies are encouraged to make policies related to the impact of technological innovations to comply with them to implement work following procedures. According to what this study shows, technological innovation positively impacts employees' satisfaction and work-life balance. When employees feel satisfied with work and feel balanced between work and personal life, this will positively impact their performance. It can directly affect the business achievement that the company wants to achieve if the employee's performance is good. The last things to make employee feels happy at work and quality of work-life increases with the presence of technological Innovation: Company have to give more real pleasure like flexible work time, games competition between employee, and also rewarding to employee likes Door Prize to appreciate them in this during Pandemic time when they can achieve the KPI of the Job, and this research has proven that employees can get higher self-esteem, more confidence, more willingness to take on new challenges, and more eagerness to be innovative, and employee motivation related to rewards and recognition impact.

The limitation of this research is that this research is only conducted in Indonesia, especially in the Greater Jakarta area, which is aimed at individuals working in the banking sector related to technological innovation for employees working in the COVID-19 pandemic era. Therefore, there is a limitation in the demographic classification of research participants, allowing for differences in thoughts or attitudes towards technological innovations carried out by companies towards employees in non-bank companies and outside the research area.

\section{References}

Akpa, V., Egbuta, O., Akinlabi, B., \& Magaji, N. (2019). Work-life balance and employee performance: A study of selected deposit money banks in Lagos State, Nigeria. The Journal of Social Sciences Research, 1787-1795. https://doi.org/10.32861/jssr.512.1787.1795 
Al-Saidi, R. M. M. (2015). The impact of advanced technology on work-life balance for the administrative staff at UNRWA-Gaza field office [Islamic University]. https://search.emarefa.net/detail/BIM-687259

Ameme, B., \& Wireko, J. (2016). Impact of technological innovations on customers in the banking industry in developing countries. The Business and Management Review, 7(3), 388-397.

Annur, C. M. (2020, September 24). Aset dua bank syariah milik BUMN turun pada kuartal II2020. Retrieved from https://databoks.katadata.co.id/datapublish/2020/09/24/aset-dua-banksyariah-milik-bumn-turun-pada-kuartal-ii-2020

Aselage, J., \& Eisenberger, R. (2003). Perceived organizational support and psychological contracts: A theoretical integration. Journal of Organizational Behavior - J ORGAN BEHAV, 24, 491-509. https://doi.org/10.1002/job.211

Attar, G., \& Sweis, R. (2010). The relationship between information technology adoption and job satisfaction in contracting companies in Jordan. Electronic Journal of Information Technology in Construction, 15, 44-63.

Awan, D. A. G., \& Asghar, I. (2014). Impact of employee job satisfaction on their performance: A case study of banking sector in Muzaffargarh District, Pakistan. Global Journal of Human Resource Management, 2(4), 71-94.

Bakker, A. B., \& Costa, P. L. (2014). Chronic job burnout and daily functioning: A theoretical analysis. Burnout Research, 1(3), 112-119. https://doi.org/10.1016/j.burn.2014.04.003

Belias, D., Koustelios, A., Sdrolias, L., Koutiva, M., \& Zournatzi, E. (2013). Job burnout Greek Bank employees: A Case Study. International Journal of Human Resource Management and Research, 3(2), 105-120.

Brown, S. P., \& Peterson, R. A. (1994). The effect of effort on sales performance and job $\begin{array}{llll}\text { satisfaction. } \quad \text { Journal } & \text { 70-80. }\end{array}$ https://doi.org/10.1177/002224299405800206

Catriana, E. (2020, June 18). Dampak pandemi Covid-19 ke penggunaan teknologi. Retrieved from https://money.kompas.com/read/2020/06/18/210000826/dampak-pandemi-covid-19-kepenggunaan-teknologi

Ciner, L. (2019, October 31). How to improve employee performance in 6 Steps. WalkMe Blog. https://blog.walkme.com/how-to-improve-employee-performance/

Cranny, E. S. (2014). Determinants of job satisfaction among police officers. Int. R. Modern Social, 24(1), 109-116.

Daniel. (2015). Analisis pengaruh image, perceived technical quality, perceived functional quality, dan perceived price terhadap revisit intention, melalui perceived value dan satisfaction suatu studi pada fame Hotel Gading Serpong [Bachelor_thesis, Universitas Multimedia Nusantara]. https://kc.umn.ac.id/346/

Demerouti, E., Verbeke, W. J. M. I., \& Bakker, A. B. (2005). Exploring the relationship between a multidimensional and multifaceted burnout concept and self-rated performance. Journal of Management, 31(2), 186-209. https://doi.org/10.1177/0149206304271602

Ezeanyim, E. E., Ufoaroh, E. T., \& Ajakpo. (2019). The impact of job satisfaction on employee performance in selected public enterprise in Awka, Anambra State. Global Journal of Management and Business Research, 19(7).

Fazili, A. I., \& Khan, O. F. (2017). A study on the impact of ICT on work life balance. Life Science Journal, 14(5), 1-4. https://doi.org/10.7537/marslsj140517.01

Goldman, S. L. (2020, July 16). Technological Innovation. Retrieved from https://www.encyclopedia.com/science/encyclopedias-almanacs-transcripts-andmaps/technological-innovation

Gorji, M., \& Vaziri, S. (2018). The survey job burnout status and its relation with the performance of the employees (Case study: Bank). 14.

Greenberg, J., \& Baron, R. A. (2000). Behavior in organizations: Understanding and managing the human side of work. Prentice Hall. 
Greenhaus, J., Collins, K., \& Shaw, J. (2003). The relation between work-family balance and quality of life. Journal of Vocational Behavior, 63, 510-531. https://doi.org/10.1016/S00018791(02)00042-8

Hair, J., Ringle, C., \& Sarstedt, M. (2011). PLS-sem: Indeed a silver bullet. The Journal of Marketing Theory and Practice, 19, 139-151. https://doi.org/10.2753/MTP1069-6679190202

Handayani, A., Afiati, T., \& Adiyanti, M. G. (2015). Studi eksplorasi makna keseimbangan kerja keluarga pada ibu bekerja. 30-36. https://repository.ugm.ac.id/274530/

Harrington, B., \& Ladge, J. J. (2009). Work-life integration: Present dynamics and future directions for organizations. Organizational Dynamics, 38(2), 148-157. https://doi.org/10.1016/j.orgdyn.2009.02.003

Khalid, A., Pan, F., Li, P., Wang, W., \& Ghaffari, A. S. (2019). The impact of occupational stress on job burnout among bank employees in Pakistan, with psychological capital as a mediator. Frontiers in Public Health, 7, 410. https://doi.org/10.3389/fpubh.2019.00410

Khatri, P. V., \& Behl, J. (2013). Impact of work-life balance on performance of employees in the organisations. Global Journal of Business Management: GJBM, 7(1), 39-47.

Kim, H. K. (2014). Work-life balance and employees' performance: The mediating role of affective commitment. Global Business and Management Research: An International Journal, 6(1), 37-51.

Knani, M. (2013). Exploratory study of the impacts of new technology implementation on burnout and presenteeism. International Journal of Business and Management, 8(22), 92-97. https://doi.org/10.5539/IJBM.V8N22P92

Kotoroi, G. L. (2015). Impact of inromation technology in banking innovations: A case of Azania Bank Limited Tegeta - Dar ES Salaam. International Journal of Scientific and Research Publications, 5(6).

Lockwood, N. (2003). Work/life balance: Challenges and solutions. Society for Human Resource Management.

Middleton, F. (2019, July 3). Reliability vs validity: What's the difference? Scribbr. Retrieved from https://www.scribbr.com/methodology/reliability-vs-validity/

Ndulue, T. I., \& Ekechukwu, H. C. (2016). Impact of job satisfaction on employees performance: A study of Nigerian Breweries Plc Kaduna State Branch, Nigeria. Kuwait Chapter of Arabian Journal of Business and Management Review, 5(11), 13-23. https://doi.org/10.12816/0031600

Obeng, A. Y., \& Boachie, E. (2018). The impact of IT-technological innovation on the productivity of a bank's employee. Cogent Business \& Management, 5(1), 1470449. https://doi.org/10.1080/23311975.2018.1470449

Osman, S., Shariff, S. H., \& Lajin, M. N. A. (2016). Does innovation contribute to employee performance?. Procedia-Social and Behavioral Sciences, 219, 571-579. https://doi.org/10.1016/j.sbspro.2016.05.036

Parkes, L. P., \& Langford, P. H. (2008). Work-life balance or work-life alignment? A test of the importance of work-life balance for employee engagement and intention to stay in organisations. Journal of Management \& Organization, 14(3), 267-284. https://doi.org/10.5172/jmo.837.14.3.267

Ratna, R. (2016). The impact of information technology on job related factors like health and safety, job satisfaction, performance, productivity and work life balance. Journal of Business \& Financial Affairs, 05. https://doi.org/10.4172/2167-0234.1000171

Rehman, W., Yousaf, S., \& Naeem, H. (2015). Impact of burnout on employees' performance: An analysis of banking industry. World Review of Entrepreneurship, Management and Sustainable Development, 11, 88. https://doi.org/10.1504/WREMSD.2015.066980

Richie. (2019, March 21). Perbandingan SEM dengan SEM PLS. https://www.mobilestatistik.com/perbandingan-sem-dengan-sem-pls/ 
Ritacco, G., Jankome, P., \& Mangori, M. (2013). The Impact of stress and burnout on employees' performance at Botswana Power Corporation. Interdisciplinary Journal of Contemporary Research In Business, 5(6), 795-824.

Salanova, M., \& Schaufeli, W. B. (2000). Exposure to information technology and its relation to burnout. Behaviour \& Information Technology, 19(5), 385-392. https://doi.org/10.1080/014492900750000081

Schaufeli, W. B., \& Greenglass, E. R. (2001). Introduction to special issue on burnout and health. Psychology \& Health, 16(5), 501-510. https://doi.org/10.1080/08870440108405523

Sockel, H., Mak, B., \& Bucholz, J. (2004). The affects of diffusion of technology innovation on burnout. Journal of Management Systems, 16(1).

Stefanie, K., Suryani, E., \& Maharani, A. (2020). Flexible work arrangement, work life balance, kepuasan kerja, dan loyalitas karyawan pada situasi Covid-19. Jurnal Ilmiah MEA (Manajemen, Ekonomi, \& Akuntansi), 4(3), 1725-1750. https://doi.org/10.31955/mea.vol4.iss3.pp1725-1750

Sutrisno, E. (2011). Manajemen Sumber Daya Manusia. Kencana Prenada Media Group.

Tabassum, U., Khan, B., Sherani, A. W., \& Khan, I. (2016). The relationship between job satisfaction and job performance among employees: A case of commercial banks in Punjab City, Pakistan. PM World Journal, V(VIII), 17.

Taghipour, A., \& Dejban, R. (2013). Job performance: Mediate mechanism of work motivation. Procedia - Social and Behavioral Sciences, 84, 1601-1605. https://doi.org/10.1016/j.sbspro.2013.06.796

Thevanes, N., \& Mangaleswaran, T. (2018). Relationship between work-life balance and job performance of employees. IOSR Journal of Business and Management, 20, 11-16. https://doi.org/10.9790/487X-2005011116

Wu, G., Hu, Z., \& Zheng, J. (2019). Role stress, job burnout, and job performance in construction project managers: The moderating role of career calling. International Journal of $\begin{array}{lllll}\text { Environmental Research and Public Health, 16(13), } 2394 . & \end{array}$ https://doi.org/10.3390/ijerph16132394

Yudianto, A., \& Nurpratama, M. (2021). Peningkatan usaha dan inovasi pada industri kecil dan menengah (IKM) Produk Mekaya Losarang Kabupaten Indramayu. KANGMAS: Karya Ilmiah Pengabdian Masyarakat, 2(2), 165-170. https://doi.org/10.37010/kangmas.v2i2.327

Yuliani, P. A. (2020, April 18). PSBB, jumlah pekerja yang WFH di Jakarta malah berkurang. Retrieved from https://mediaindonesia.com/megapolitan/305194/psbb-jumlah-pekerja-yangwfh-di-jakarta-malah-berkurang 